Author version: J. Oceanogr., vol.66(1); 2010; 133-146

\title{
Paleoclimatic and diagenetic history of the late Quaternary sediments in a core from the southeastern Arabian Sea: geochemical and magnetic signals
}

VENIGALLA PURNACHANDRA RAO ${ }^{{ }^{*}}$, PRATIMA MOHAN KESSARKAR ${ }^{1}$, MELOTH THAMBAN $^{2}$ AND SHIVA KUMAR PATIL ${ }^{3}$

${ }^{1}$ National Institute of Oceanography, Council of Scientific and Industrial Research, Dona Paula - 403

004, Goa, India

${ }^{2}$ National Centre for Antarctic and Ocean Research, Headland Sada-403 804, Goa, India

${ }^{3}$ Dr. K. S. Krishna Geomagnetic Research Laboratory, Indian Institute of Geomagnetism, Allahabad-

221 505, Uttar Pradesh, India

\section{ABSTRACT}

The geochemical and rock-magnetic investigations were carried out on a sediment core collected from the SE Arabian Sea at $1420 \mathrm{~m}$ depth in oxygenated waters below the present day oxygen minimum zone. The top $250 \mathrm{~cm}$ sediments of the core represent the last $35 \mathrm{kaBP}$. The $\delta^{18} \mathrm{O}$ values of Globigerinoides ruber are heaviest during the Last Glacial Maximum (LGM) and appear unaffected by low-saline waters transported from the Bay of Bengal by stronger northeast monsoon and West Indian

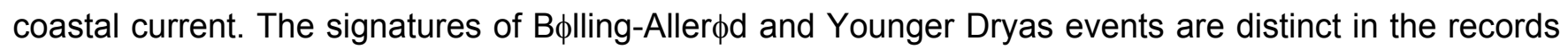
of magnetic susceptibility, organic carbon $(\mathrm{OC})$ and $\delta^{18} \mathrm{O}$. Glacial sediments show higher $\mathrm{OC}, \mathrm{CaCO}_{3}$, $\mathrm{Ba}, \mathrm{Mo}, \mathrm{U}$ and $\mathrm{Cd}$, while the early to late Holocene sediments show increasing concentrations of $\mathrm{OC}$, $\mathrm{CaCO}_{3}, \mathrm{Ba}, \mathrm{Cu}, \mathrm{Ni}$ and $\mathrm{Zn}$ and decreasing concentrations of Mo, $\mathrm{U}$ and $\mathrm{Cd}$. Productivity induced lowoxygenated bottom waters and reducing sedimentary conditions during glaciation and, productivity and oxygenated bottom waters in Holocene are responsible for their variation. The core exhibits different stages of diagenesis at different sediment intervals. The occurrence of fine-grained, low-coercivity, ferrimagnetic mineral during glacial period is indicative of its formation in organic-rich, anoxic sediments, that may be analogous to the diagenetic magnetic enhancement known in sapropels of the Mediterranean Sea and Japan Sea. The glacial sediments exhibiting reductive diagenesis with anoxic sedimentary environment in this core correspond to reductive diagenesis and intermittent bioturbation (oxygenation) reported in another core in the vicinity. This suggests that the low-oxygenated bottom water conditions during glacial times should not be generalized, but are influenced locally by productivity, sedimentation rates and sediment reworking.

Keywords: rock magnetic properties, redox-sensitive elements, sedimentary environment, diagenetic magnetic minerals, productivity, SE Arabian Sea, late Quaternary

${ }^{*}$ Corresponding author, E-mail: vprao@nio.org 


\section{Introduction}

Sediments in the Arabian Sea form an important archive for understanding climate and environmental conditions during the Quaternary. For more than two decades, numerous sedimentary records have been investigated from its northwestern and northeastern margins and deep Arabian Sea (Van Campo et al., 1982; Clemens and Prell, 1990; Shimmield et al., 1990; Shimmield and Mowbray 1991; Prell et al., 1992; Sirocko et al., 1996, 2000; Reichart et al., 1997; Schulz et al., 1998; von Rad et al., 1999; Shenetger et al., 2000). The records reveal the history of upwelling related productivity driven by the monsoons. The past variations in productivity are related to climate change through glacial/interglacial cycles and are linked to the global parameters such as ice volume, deep water circulation and continental climate. The southeastern Arabian Sea is affected by both southwest and northeast monsoons and a few sedimentary records report productivity and climate change (Sarkar et al., 1990, 1993; Thamban et al., 2001; Pattan et al., 2003; Banakar et al., 2005, Singh et al., 2006). As the strength of the monsoons varies significantly within the Arabian Sea during glacial/interglacial cycles (Duplessy, 1982), one would expect significant regional variations in productivity. The biological and geochemical proxies developed for productivity in one area may have limitations to use in other areas, as these proxies are affected by various other processes (bioturbation, diagenesis etc.), that may destroy or mask the primary geochemical signals (Shenetger et al., 2000; Rao et al., 2008). On the other hand, rock magnetic parameters (concentration, mineralogy and grain size) of the sediments respond to environmental change and have been used extensively to address provenance, climate-related and diagenetic changes (Karlin, 1990; Bloemendal et al., 1988; Leslie et al., 1990; Vigliotti et al., 1999). It has been shown that the variations in magnetic susceptibility are related to global oxygen isotope fluctuations (Vigliotti, 1997). They respond to a global model of the atmospheric and oceanic circulation and are coincident with Earth's orbital periods (Bloemendal et al., 1988). The affect of diagenesis on magnetic minerals (dissolution of detrital magnetite and other iron-bearing phases and, formation of new magnetic minerals by (bio)authigenesis) is well known: (Robinson et al., 2002; Liu et al., 2004; Rey et al., 2005; Hayashida et al., 2007). In this paper a multiproxy approach has been adopted to determine the past climate and diagenetic conditions. The objectives of the paper are to investigate sedimentological, geochemical and 
rock magnetic characteristics of the sediments in a core from the southeastern Arabian Sea and compare these results with other cores in the vicinity to better understand climate, oceanographic and diagenetic conditions during the late Quaternary.

A sediment core SK148/4 collected from the southwestern margin of India, off Thiruvananthapuram (Fig. 1) at $1420 \mathrm{~m}$ depth in oxygenated waters below the present day depths of oxygen minimum zone (OMZ: 150-900 m) was investigated. The results of this core were compared with three other sediment cores located in the vicinity (see Fig. 1). Core AAS $62 / 2$ is from 1380 m depth located to the north of the core SK 148/4, while cores SK 20/185 and SS $3827 \mathrm{G}$ are from $3564 \mathrm{~m}$ and $3118 \mathrm{~m}$ depths, located towards west and south, respectively. Strong seasonal winds during the southwest monsoon (SWM; June - September) and northeast monsoon (NEM; November - February) invoke large seasonal changes in hydrography and particle fluxes. During present times, the SWM is strong in the Arabian Sea and induces upwelling of cold, nutrient-rich sub-surface waters leading to an enhanced productivity. The NEM is weak in the Arabian Sea and productivity occurs due to winter cooling that drives convective mixing and injection of nutrients to the euphotic zone.

\section{Materials and Methods}

During the $148^{\text {th }}$ cruise of ORV Sagar Kanya a $2.8 \mathrm{~m}$ long gravity core was recovered at 1420 $m$ water depth from the southwestern margin of India (Fig. 1). The sediments throughout the length of the core are olive grey, clayey silt/silty clays. The core was sectioned onboard at 1 $\mathrm{cm}$ interval. Sub-samples were dried at $<40{ }^{\circ} \mathrm{C}$. Organic carbon (OC) content of the 69 sediment intervals was determined using CNS analyser (NCS 2500). The reproducibility of OC was better than $1 \%$. The $\mathrm{CaCO}_{3}$ content of 88 sediment samples was measured using a coulometer with reproducibility of measurements better than $5 \%$. Grain size analyses were made on 175 carbonate and organic matter free samples ( $1 \mathrm{~N} \mathrm{HCl}$ and $\mathrm{H}_{2} \mathrm{O}_{2}$ treated), using Malvern Laser Particle size analyzer (Master-Sizer 2000) and the percentage of clay $(<4 \mu \mathrm{m})$ volume was used for the present study. Powdered samples were weighed accurately and treated with $1 \mathrm{~N} \mathrm{HCl}$, washed with distilled water to remove acid, dried and weighed again. The acid-insoluble residue (AIR) of the sample was calculated by subtracting this weight from the 
total weight. For the oxygen isotope analyses, mono-specific, planktonic foraminifer Globigerinoides ruber (250-300 $\mu \mathrm{m}$ size fraction) was handpicked from the coarse fraction and repeatedly cleaned ultrasonically. About $10 \mathrm{G}$. ruber tests were selected from each of the 60 sediment intervals and analyzed for stable oxygen isotopes on a Micromass Optima IRMS system at the Geological Survey of Japan (GSJ), Tsukuba. All the values are given in \%o relative to PDB. Repetitive analysis of the NBS 19 and internal laboratory standards revealed an external analytical error within $\pm 0.05 \%$. Accelerator Mass Spectrometer (AMS) ages were measured on the same foraminifers picked up from five sediment intervals, using the NOSAMS facility at Woods Hole, USA. The radiocarbon ages were calibrated to the calendar ages, using calib 5.02 (Stuiver et al., 2005) and calendar ages are discussed throughout the study (Table 1). High resolution magnetic measurements were made on 175 sediment intervals using facilities at Dr. K. S. Krishna Geomagnetic Research Laboratory, Allahabad, following detailed methodology reported in Kumar et al. (2005). The three point average of all these parameters and their distributions are shown in Fig. 4.

For inorganic elemental chemistry, powdered sediments were weighed accurately to $\sim 100 \mathrm{mg}$, transferred to clean Teflon beakers and open acid digestion was carried out at GSJ, Tsukuba. The sediments were repeatedly digested by treating with a mixture of $\mathrm{HCl}, \mathrm{HNO}_{3}$, $\mathrm{HClO}_{4}$ and $\mathrm{HF}$ under controlled conditions. Finally, $3 \mathrm{ml}$ of $\mathrm{HNO}_{3}$ was added to the digested samples and the entire solution was brought to a standard volume. Major and minor elements were measured using ICP-AES (Seiko SPS 7800) and trace elements using ICP-MS (Yokogawa Analytical Systems PMS-200) at GSJ, Tsukuba. Accuracy and reproducibility were confirmed by repeated measurements of the GSJ internal standards, JA2, JB2, JG1A and JR1. Reproducibility of the measurements for all elements reported here was better than $\pm 8 \%$. Following the seminal works of other investigators on the geochemistry of the sediments of the Arabian Sea (Hermelin and Shimmield, 1990; Shimmield and Mowbray, 1991; Reichart et al., 1997; Shenetger et al., 2000; Van der Weijden et al., 2006), elements were classified into terrigenous ( $\mathrm{Fe}, \mathrm{K}, \mathrm{Rb}, \mathrm{Sc}, \mathrm{Zn}$, Th and $\mathrm{V}$ ), biogenous and organic-associated $\left(\mathrm{CaCO}_{3}, \mathrm{OC}, \mathrm{Sr}\right.$, $\mathrm{Cu}, \mathrm{Ni}, \mathrm{Zn}, \mathrm{Sr}, \mathrm{Ba}$ ) and redox-sensitive elements (Mo, $\mathrm{U}$ and $\mathrm{Cd}$ ). In order to correct for dilution by terrigenous sediment component, element concentrations were normalized by $\mathrm{Al}$ and their down core distributions are shown in Figs. 5-7. 


\section{Results}

\subsection{Chronology and sedimentation rates}

The age model of the core is based on five calibrated AMS ${ }^{14} \mathrm{C}$ dated intervals and comparison of our $\delta^{18} \mathrm{O}$ record in marine isotope stage (MIS) 3 interval with that of SPECMAP. The top 250 $\mathrm{cm}$ sediments of the core represent the last $35 \mathrm{kaBP}$, deposited at $\sim 7 \mathrm{~cm} / \mathrm{ka}$. The rates of sedimentation for different intervals of the core vary from $4.5 \mathrm{~cm} / \mathrm{ka}$ to $8.7 \mathrm{~cm} / \mathrm{ka}$, and are highest for the glacial and late Holocene sediments, and lowest for deglacial and early Holocene sediments (16-6.6 kaBP - Fig. 2).

\subsection{Variations in $\delta^{18} \mathrm{O}, \chi_{\mathrm{If}}$, acid-insoluble residue, clay, $\mathrm{OC}$ and $\mathrm{CaCO}_{3}$}

The $\delta^{18} \mathrm{O}$ stratigraphy of the core is admittedly a low resolution record because of low sedimentation rates. The $\delta^{18} \mathrm{O}$ values in MIS 3 are lighter, $-0.75 \%$ o to $-1.5 \%$, and become gradually heavier towards Last Glacial Maxima (LGM), with the heaviest value of $-0.5 \%$ at 18.2 kaBP (Fig. 3). The $\delta^{18} \mathrm{O}$ excursion to low values starts during deglaciation and occurs gradually in three steps, punctuated by heavier values at 15.5 and $12.1 \mathrm{kaBP}$. The $\delta^{18} \mathrm{O}$ values further reduce to $-2.5 \%,-2.7 \%$ and $-3.2 \%$ at $\sim 11.5 \mathrm{kaBP}, \sim 8.8 \mathrm{kaBP}$ and $\sim 3 \mathrm{kaBP}$, respectively. The $\delta^{18} \mathrm{O}$ resembles that of global $\delta^{18} \mathrm{O}$ signal during warm period, except that the values are more negative. The acid-insoluble residue (AIR) content is lowest during MIS 3, slightly higher during the LGM with a minor peak of high values between 18 and $16 \mathrm{kaBP}$. AIR starts increasing at $\sim 15.7 \mathrm{kaBP}$ with increase in the reduction of $\delta^{18} \mathrm{O}$ and attains the highest value at $\sim 11 \mathrm{kaBP}$. Thereafter it shows a decreasing trend towards core top. Silt is the dominant component in MIS 3 and LGM sediments. The total clay volume is low in the sediments between 36 and 16 kaBP, but increases sharply to high values between $\sim 16$ and 12 kaBP with a minor trough of low values between 12 and $10 \mathrm{kaBP}$ (Fig. 3). The low-frequency magnetic susceptibility $\left(\chi_{\text {If }}\right)$ varies between 15 and $3 \times 10^{-8} \mathrm{~m}^{3} / \mathrm{kg}$, with peaks of high $\chi_{\text {If }}$ and troughs of low $\chi_{\text {If }}$ through out the core. Larger peaks of high $\chi_{\text {lf }}$ coincide with strongly reduced $\delta^{18} \mathrm{O}$ values during the Holocene. Several peaks of high $\chi_{\text {lf }}$ occur both in deglacial and glacial sediments. A broad trough of low $O C$ values amid high $O C$ values during the glacial and late Holocene sediments is characteristic of the core. OC starts decreasing from $18 \mathrm{kaBP}$, maintaining low values until $10.5 \mathrm{kaBP}$ and then increases gradually towards the core top. The mass accumulation rates 
(MAR) of $O C$ follow that of $O C$ distribution. The ratio of organic carbon to total nitrogen is largely in the range $7-11$ which is indicative of marine OC throughout the core.

\subsection{Rock magnetic properties}

Magnetic mineral concentrations are high for the sediments at the core top and decrease towards the bottom. Low-frequency magnetic susceptibility $\left(\chi_{\mathrm{If}}\right)$ reflects bulk concentrations of magnitizable material and is also related to the grain size of magnetic components. It exhibits several narrow and broad peaks of high $\chi_{\text {If }}$ and broad troughs of low $\chi_{\text {If }}$ throughout the core (Fig. 4). The anhysteretic susceptibility $\left(\chi_{A R M}\right)$ and Saturation isothermal remnant magnetization (SIRM) provide information on concentrations but their ratio with $\chi_{\text {If }}$ is largely related to grain size (Oldfield, 1991). The $\chi_{\text {ARM }}$ values are $\sim 150 \times 10^{-8} \mathrm{~m}^{3} / \mathrm{kg}$ at the core top but decrease sharply to $15 \times 10^{-8} \mathrm{~m}^{3} / \mathrm{kg}$ within the top $10 \mathrm{~cm}$ of the sediment (2 kaBP). It fluctuates largely between 2.5 and $7.5 \times 10^{-8} \mathrm{~m}^{3} / \mathrm{kg}$ in the remaining portion of the core. SIRM is also high at the core top, but distributed mostly around decreased values; its down core decrease is quite distinct. S-ratio is related to the proportions of low-coercivity to high-coercivity magnetic minerals. The sediments of the last $7 \mathrm{kaBP}$ exhibit a broad trough of low values of magnetic concentration, grain size and mineralogy variables and correspond to high OC (4.1-1.2\%). The sediments between 7 and $17 \mathrm{kaBP}$ are characterized by a broad trough of low OC, accompanied by narrow peaks of high $\chi_{\text {If }}$ and matching peaks in other magnetic concentration, grain size and mineralogy parameters. The peak in $\chi$ lf profile at $10 \mathrm{kaBP}$ is represented by a broad trough of low values in $\chi_{\text {ARM }}, S I R M, \chi_{A R M} / \chi_{\text {If }}$ and $\chi_{A R M} / S I R M$ and reduced S-ratio. The sediments of 17-35 kaBP contain high OC. The peaks in $\chi_{\text {If }}$ do not resemble those in $\chi_{\text {ARM }}$ and SIRM at several intervals both in 7-17 kaBP and 17-35 kaBP. Small, narrow low amplitude peaks in $\chi_{\text {If }}$ centered at $\sim 17$ and 22 kaBP correspond to large, broad peaks of high $\chi_{\text {ARM }}$, and increased $\chi_{A R M} / \chi_{\text {If }}, \chi_{A R M} / S I R M$ and high S-ratios (light bands in Fig. 4). The peaks in $\chi_{\text {If }}$ profile at $\sim 18 \mathrm{kaBP}, \sim 20 \mathrm{kaBP}$ (dark bands in Fig. 4) and to some extent $\sim 25 \mathrm{kaBP}$ match with low $\chi_{\text {ARM }}, S I R M, \chi_{\text {ARM }} / \chi_{\text {Iff }}, \chi_{\text {ARM }} / S I R M$ and decreased S-ratio. The peaks in $\chi_{\text {If }}$ profile at $\sim 28 \mathrm{kaBP}$ are represented by minor peaks in $\chi_{\text {ARM }}$ and SIRM profiles and low S-ratios. 


\subsection{Variations in biogenic, terrigenous and redox-sensitive elements}

For convenience of description the core is divided into sections shown in figures 3-7. The boundaries of sections do not correspond to marine isotope stages but overlap one over the other. The element/Al concentrations of $\mathrm{Rb}, \mathrm{Zr}, \mathrm{V}, \mathrm{Ba}$, and $\mathrm{Zn}$ are lower and $\mathrm{Fe}, \mathrm{K}, \mathrm{Ca}, \mathrm{Sr}$, Mo and $U$ are higher than that of shale at different sediment intervals (see Figs. 5-7). The Alnormalized profiles of $\mathrm{Cu}, \mathrm{Ni}$ and $\mathrm{Zn}$ appear to imitate that of $\mathrm{OC}$, and $\mathrm{Sr}$ with $\mathrm{CaCO}_{3}$ (Fig. 5). $\mathrm{OC}$ exhibits strong correlation with $\mathrm{Ba} / \mathrm{Al}, \mathrm{Cu} / \mathrm{Al}, \mathrm{Ni} / \mathrm{Al}$ and $\mathrm{Zn} / \mathrm{Al}$ and moderate correlation with $\mathrm{CaCO}_{3}$ in Holocene sediments. Ba/Al shows strong correlation with $\mathrm{CaCO}_{3}$ (Table 2; Fig. 5). OC shows good correlation with $\mathrm{Cu} / \mathrm{Al}, \mathrm{Ni} / \mathrm{Al}$ and $\mathrm{Zn} / \mathrm{Al}$, weak correlation with $\mathrm{Ba} / \mathrm{Al}$ and no correlation with $\mathrm{CaCO}_{3}$ for the deglacial (17-11 kaBP) sediments. $\mathrm{CaCO}_{3}$ is negatively correlated with $\mathrm{Ba} / \mathrm{Al}$ in these sediments. OC shows no correlation with $\mathrm{Cu} / \mathrm{Al}, \mathrm{Ni} / \mathrm{Al}$ and $\mathrm{Zn} / \mathrm{Al}$ for the glacial (17-24 kaBP) and pre-glacial (24-35 kaBP) sediments. It moderately correlates with $\mathrm{Ba} / \mathrm{Al}$ and $\mathrm{CaCO}_{3}$ for the glacial sediments but weakly with pre-glacial sediments (Table 2). The Al-normalized ratios of $\mathrm{Fe}, \mathrm{K}, \mathrm{Rb}, \mathrm{Sc}, \mathrm{Zr}$, Th and $\mathrm{V}$ show distinct highs and lows: large peaks of high ratios of these elements match with low $\chi_{\text {If }}$ in glacial sediments and, peaks of low ratios of these elements with peaks of high $\chi_{\text {If }}$ (Fig. 6). The Mo, $U$ and $C d$ values at different intervals in the core range from 2.4 to $7.9 \mathrm{ppm}, 7$ to $21.8 \mathrm{ppm}$ and 0.22 to $0.57 \mathrm{ppm}$, respectively. Sirocko et al. (2000) reported Mo, U and Cd concentrations up to $6.29 \mathrm{ppm}, 12$ ppm and 0.8 ppm, respectively for modern and Holocene sediments of the SW margin of India. The peak U/Al, Cd/Al and Mo/Al ratios are higher by 2.0, 2.5 and 4 times, respectively in glacial sediments than those in Holocene. The Mo distribution replicates that of U. The U/AI and Mo/Al ratios are peaked at $\sim 32 \mathrm{kaBP}$ and then decrease until $25 \mathrm{kaBP}$. Thereafter their ratios increase progressively until $22 \mathrm{kaBP}$ and then decrease gradually until $17 \mathrm{kaBP}$ (Fig. 7). Their ratios are consistently low and decrease uniformly during the Holocene. The distribution of $\mathrm{Cd}$ is broadly similar to that of $\mathrm{U}$ and Mo, except that its maximum concentration occurs at 17 kaBP.

\section{Discussion}

\subsection{Climatic and oceanographic conditions}

The $\delta^{18} \mathrm{O}$ values are heaviest in LGM sediments and lightest in Holocene with $\Delta \delta^{18} \mathrm{O}$ amplitude of $-2.2 \%$ (Fig. 3). Duplessy (1982) reported weaker SW monsoon (SWM) and a stronger NE 
monsoon (NEM) in the northern Indian Ocean during LGM than in the present day. The enhanced NE winds during the NEM cause high precipitation over the southeast Peninsular India and bring large quantities of fresh water to the SW Bay of Bengal. These low-saline waters are transported to the SE Arabian Sea by the northeast monsoon current (NEMC) and West India Coastal Currents (WICC) (see current direction in Fig. 1). Owing to the fact that weaker SWM and stronger NEM existed during LGM and the location of the core is in an area under the influence of NEMC and WICC, one would expect lighter $\delta^{18} \mathrm{O}$ values for near-surface dwelling Globigerinoides ruber during the LGM. The heaviest $\delta^{18} \mathrm{O}$ values, however suggest that the NEM might not have been stronger during the LGM. Tiwari et al. (2005) reported a significant reduction in $\delta^{18} \mathrm{O}(\sim 1.5 \%)$ during 19-17 kaBP in a core SS 3827G from the equatorial Arabian Sea (Figs. 1 and 8 ) and attributed this reduction to the strong influence of low-saline waters brought by the NEMC. The maximum reduction in $\delta^{18} \mathrm{O}$ for $\mathrm{G}$. ruber during 21- $17 \mathrm{kaBP}$ is found to be $\sim 0.25 \%$ in core SK $148 / 4, \sim 0.25 \%$ in core AAS $62 / 2$ and $\sim 0.5 \%$ in core SK 20/185 (see Fig. 8). This suggests that the affect of low-saline, Bay of Bengal waters is least along the SW margin of India during LGM and perhaps more towards west, away from the margin. Alternatively, convective mixing due to stronger NEM during LGM may have quickly mixed up the surficial cap of low-saline waters and nullified its affect on $\delta^{18} \mathrm{O}$. Stronger convective mixing causes injection of nutrients to the euphotic zone and increase in productivity. Relatively high organic carbon and Ba/Al ratios in glacial sediments indeed attest high productivity (see below). The $\delta^{18} \mathrm{O}$ excursion towards lighter values at $\sim 15.7 \mathrm{kaBP}$ coincides with increase in acid-insoluble residue (AIR) content and clay volume (Fig. 3); this may represent river input and enhancement of summer SW monsoon, as also reported by several investigators in this region (Thamban et al., 2001; Sinha et al., 2005; Tiwari et al., 2005; Rao et al., 2008).

By comparing the records of $\delta^{18} \mathrm{O}$, magnetic susceptibility $\left(\chi_{\mathrm{If}}\right)$ and $\mathrm{OC}$ it is possible to infer some global climatic events. The B $\phi$ lling-Aller $\phi d$ (B-A) event at 15.5-13 kaBP, a warming event is reflected in our core by reduced $\delta^{18} \mathrm{O}$ values, strong peak in $\chi_{\text {lf }}$ and relatively increased $\mathrm{OC}, \mathrm{Ba} / \mathrm{Al}, \mathrm{Sr} / \mathrm{Al}$ and $\mathrm{CaCO}_{3}$ (Figs. 3 and 5) indicating increase in monsoon precipitation and productivity during this time. Sinha et al. (2005) suggested that the SW Indian monsoon precipitation during B-A event was coupled with the variations in the East Asian 
monsoon and North Atlantic climate. Similarly, the gradual reduction in $\delta^{18} \mathrm{O}$ at $\sim 13.7-11.8 \mathrm{ka}$ was interrupted by heavier $\delta^{18} \mathrm{O}$ at $\sim 12 \mathrm{kaBP}$ (Fig. 3), which correspond to the mid-point of a peak in $\chi_{\text {If }}$ profile (Fig. 3). This interval is assigned to as Younger Dryas (YD) event that has been reported in sediments of the eastern Arabian Sea (von Rad et al., 1999; Singh et al., 2006; Rao et al., 2008). The presence of Younger Dryas and B-A events similar to that of North Atlantic and Northwestern Arabian Sea (Schulte et al., 1999; von Rad et al., 1999) reflect that the abrupt climatic changes are of global origin suggesting common forcing agents through atmospheric circulation. At the end YD event, $\delta^{18} \mathrm{O}$ values were further reduced during early Holocene and peaked at $\sim 11.5 \mathrm{ka}, 9 \mathrm{ka}$ and $7 \mathrm{kaBP}$ with intermittent low values, suggesting major intensification of summer SWM occurred at $11.5 \mathrm{kaBP}$ and synchronous with a major climate transition recorded in Greenland (Sirocko et al., 1993). The greater reduction of $\delta^{18} \mathrm{O}$ and strong $\chi_{\text {lf }}$ peaks between 11.5 and 7 kaBP suggest that the intensified monsoon persisted during this period.

\subsection{Productivity and redox conditions}

\subsubsection{Glacial sediments}

The OC values are high and similar in glacial and late Holocene sediments (Fig. 5), despite the fact that the southwest monsoon (SWM) was stronger during Holocene and weaker during the last glaciation (Van Campo et al., 1982). The role of low-oxygenated bottom waters (Sarkar et al., 1993; Van der Weijden et al., 1999; Agnihotri et al., 2003; Pattan et al., 2003) and/or high productivity linked to the NE monsoon winds during LGM (Rostek et al., 1997; Schulte et al., 1999; von Rad et al., 1999; Thamban et al., 2001) were suggested for organic-rich sediments in the Eastern Arabian Sea. Since the organic matter content in sediments is also influenced by other factors (quality of organic matter, early diagenesis, rates of sedimentation and sediment type - see Paropkari et al., 1992), it may not serve as an independent proxy for productivity. Schnetger et al. (2000) showed that the total organic carbon is not a tracer, but $\mathrm{Ba} / \mathrm{Al}$ serves as a proxy for paleoproductivity in the sediments of deep Arabian Sea. Sediment trap experiments showed that $\mathrm{Ca}, \mathrm{Sr}$ and $\mathrm{Ba}$ associate with biogenic particles and, particulate organic matter is an effective scavenger for metals such as $\mathrm{Cu}, \mathrm{Ni}, \mathrm{Zn}$ and $\mathrm{V}$, whose concentrations are controlled by seasonally driven changes in primary productivity (Jickells et al., 1984; Shimmield and Mowbray, 1991; Schnetger et al., 2000). Ba in the offshore 
precipitates as barite by the living phytoplankton cells and thus barite content in sediments is a function of biological productivity. Dymond et al. (1992) suggested that excess Ba in sediments may serve as a proxy for particulate organic carbon (POC). Prakashbabu et al. (2002) reported excess $\mathrm{Ba}$ in Holocene sediments of the SW margin of India and suggested that although $\mathrm{Ba}$ is lost during sub-oxic diagenesis, it reflects productivity trend on this margin. Tracers such as Ba/Al (Shimmield et al., 1990; Hermelin and Shimmield, 1995), Zn/Al and Ba/Al (Reichart et al., 1997), Ni/Al and Zn/Al (von Rad et al., 1999) and Cu/Al (Shenetger et al., 2000) along with OC have been used as paleoproductivity indicators in the Arabian Sea. Although OC/Al and Ba/Al profiles show an opposite trend in deglacial sediments of core SK 148/4 (Fig. 5), OC showed moderate correlation with $\mathrm{Ba} / \mathrm{Al}(\mathrm{r}=0.51)$ and $\mathrm{CaCO}_{3}(\mathrm{r}=0.5)$, but no correlation with $\mathrm{Cu} / \mathrm{Al}$, $\mathrm{Ni} / \mathrm{Al}$ and $\mathrm{Zn} / \mathrm{Al}$ ratios $(r=-0.24$ to -0.35$)$ for the glacial sediments. All these elements however showed strong correlation with OC for Holocene sediments (Table 2). As Ba/Al also correlates well with $\mathrm{CaCO}_{3}(\mathrm{r}=0.6)$, biological productivity seems to be an important factor for organic enrichment in glacial sediments. Poor correlation of $\mathrm{Cu}, \mathrm{Ni}$ and $\mathrm{Zn}$ with $\mathrm{OC}$ may be due to their diagenetic mobilization and redistribution during reducing conditions (see below). Barite is lost in sub-oxic conditions and gets dissolved under anoxic sediments. Higher mass accumulation rate of $\mathrm{OC}$ (Fig. 3) and $\mathrm{Ba}$ may have preserved some $\mathrm{OC}$ and $\mathrm{Ba}$ leading to moderate correlation. Schenau et al. (2001) suggested that the burial efficiency of barite depends on degree of barite saturation and barite accumulation rate, Chase et al. (2001) investigated U concentrations in 50 sediment cores over a wide latitudinal and depth range in the Atlantic sector of the Southern Ocean and suggested that authigenic $U$ in glacial sediments can not be due entirely to lateral supply of POC via sediment focusing or reduction in bottom water oxygen concentrations, but reflects primarily increased particulate organic carbon. Comparison of $\mathrm{U} / \mathrm{Al}, \mathrm{Th} / \mathrm{Al}$ and $\mathrm{U} / \mathrm{Sc}$ profiles (Figs. 6-7) indicates enrichment of authigenic $U$ in glacial sediments (see below) and thus high organic flux supporting productivity. Higher surface productivity in glacial times than in deglacial times was suggested to be due to deep convective mixing related to intensified winter monsoon winds (see Rostek et al., 1997; Reichart et al., 2002).

The concentrations of $\mathrm{Mo}, \mathrm{U}$ and $\mathrm{Cd}$ are 2 to 4 times greater in glacial sediments than those in Holocene (Fig. 7). These redox-sensitive metals are initially supplied from terrestrial 
sources via runoff from land or dust input, and are scavenged to the seafloor by adsorbing onto sinking particulate flux such as plankton organic materials (OM), Fe-, and Mn-oxides and clays (Morford and Emerson, 1999; Nameroff et al., 2002). Their enrichment in sediments depends on concentration gradients of metals, depth of the redox boundaries below the sediment-water interface, mass accumulation rates and bioturbation depths. The metals liberated during microbial decomposition of OM during early diagenesis may escape into pore water and then to overlying waters or, diffuse downwards and precipitate in the anoxic zone, depending on redox characteristics of respective elements. Therefore, their enrichment occurs immediately below the oxic / sub-oxic boundary, or at deeper depths in sediments (Thomson et al., 2001). $U$ usually occurs as $U(\mathrm{VI})$, reduces to $U$ (IV) close to the reduction of $\mathrm{Fe}(\mathrm{III})$ to $\mathrm{Fe}$ (II) and then precipitates in the sediments (Morford and Emerson, 1999). The highest U/AI coinciding with low Fe/Al at $22 \mathrm{kaBP}$ (see Figs. 6 and 7) suggests that $U$ reduction may have occurred at reduced $\mathrm{Fe}$ (III). Zheng et al. (2000) suggested that though the authigenic precipitation of $U$ is independent of sulphide production, HS created during sulfate reduction could also be a reducing agent for $U(\mathrm{VI})$. Sc is largely associated with terrigenous material, The U/Sc distribution follows that of U/AI (Fig. 7) suggesting that high $U$ content is due to authigenic enrichment in reducing conditions. It has been suggested that the Mo liberated to the pore waters does not enrich in sub-oxic sediments but precipitates as authigenic phase in anoxic sediments only when sulphate reduction becomes important (Crusius et al., 1996; Chaillou et al., 2002). The gradual increase of both U/Al and Mo/Al from 24 to 22 kaBP (Fig. 7) suggests increase in reductive diagenesis with strong anoxic conditions at $\sim 22 \mathrm{kaBP}$. The presence of fine-grained ferrimagnetite at this interval is also an indication of strong anoxic environment (see section 4.3). Cd is usually associated with plankton organic matter (OM), released to the pore waters during OM degradation and removed from solution as CdS even with trace sulphide under anoxic conditions. Therefore $\mathrm{Cd}$ enrichment is a good indicator of sulphide production (Rosenthal et al., 1995). The maximum Cd peak (at $17 \mathrm{kaBP}$ ) is located close to the glacial / deglacial boundary and spatially separated from maximum U/AI and Mo/AI peaks that occur at $\sim 22 \mathrm{kaBP}$. The gradual $\mathrm{Cd}$ enrichment indicates sulfate reducing conditions. The pronounced shift in Cd peak (Fig. 7) may be because of fluctuating input of organic matter that results in a shift of the position of the redox boundary (see Gobeil et al., 1997) and, precipitation of Cd as CdS in the presence of trace amounts of $\mathrm{H}_{2} \mathrm{~S}$. Shenetger et 
al. (2000) reported Cd peak closer ot the interface between the turbidite and pelagic carbonate sediment in the Arabian Sea and attributed to the sensitive responsive of $\mathrm{Cd}$ to the changing redox conditions. Rock magnetic parameters indicate changing redox conditions in glacial sediments (see section 4.3). Coarse fraction studies indicate lack of bioturbation and presence of dwarf benthic foraminifers, Bulimina sp., Uvigerina and Bolivina, suggesting oxygen depleted bottom water conditions favouring reducing sedimentary conditions during the glacial period.

Glacial sediments exhibiting alternate peak high and low ratios of $\mathrm{Fe} / \mathrm{Al}, \mathrm{K} / \mathrm{Al}, \mathrm{Rb} / \mathrm{Al}$, $\mathrm{Sc} / \mathrm{Al}, \mathrm{Zr} / \mathrm{Al}, \mathrm{Th} / \mathrm{Al}$ and V/Al, where the high ratios do not coincide with peak high $\chi_{\text {If }}$ but with low $\chi_{\text {If }}$ (see bands in Fig. 6), suggesting different source materials for magnetized material and detrital elements. Radioactive and heavy mineral placer sands (zircon, monazite, ilmenite and rutile) are abundant in the coastal and shelf region (Mallik et al., 1987). Iron-rich authigenic verdine and glaucony and phosphate facies were reported on the shelf and upper slope of the study region (Rao et al., 1993). Heavy minerals and green clays concentrate in coarser sediments, whereas magnetized material in finer sediments. Peak high ratios of element/Al of $\mathrm{Fe}, \mathrm{K}, \mathrm{Rb}, \mathrm{Sc}, \mathrm{Zr}$, Th and $\mathrm{V}$ could have been caused by the reworking of green clays and placers minerals from the emergent shelf and upper slope during low stands of sea level and thus exhibit enrichment at different sediment intervals than that of $\chi_{\mathrm{lf}}$. Narrow shelf $(60 \mathrm{~km})$ and steep continental slope (Rao and Wagle, 1997) favour this process and were reported by Von Stackelberg (1972) and Thamban et al. (1997) in this region. These observations imply intermittent pulses of reworking of upper slope sediments controlled the peak high detrital element/Al ratios of $\mathrm{K}, \mathrm{Rb}, \mathrm{Sc}, \mathrm{Zr}$, Th and $\mathrm{V}$ (Fig. 6). Reworking of upper slope sediments thus may have also contributed for the enrichment of $\mathrm{OC}$ in glacial sediments than in deglacial times. Sedimentation rates are also high in glacial sediments (Fig. 2). In other words, high biological productivity that induced low-oxygenated bottom waters and reducing sedimentary conditions, reworking of upper slope sediments, high sedimentation rates and lack of bioturbation are responsible for organic-rich glacial sediments. 


\subsubsection{Deglacial sediments (17-11 kaBP)}

This period in general is characterized by rise in global sea level, abrupt climatic events, and rapid fluctuations in climate at the Pleistocene - Holocene boundary. Despite lowest sedimentation rates $(4.5 \mathrm{~cm} / \mathrm{ka})$ that prevent resolution of climatic events, the B-A event, and Younger Dryas event can be discerned (Fig. 3). The planktonic $\delta^{18} \mathrm{O}$ excursion to low values correlates well with the increase in Ba/Al ratio, a feature also observed by several others in sediment cores from different parts of the Arabian Sea (see Shimmield and Mowbray, 1991; Reichard, et al. 1997; Shenegar et al., 2000; Pattan et al., 2003). As Ba, excess Ba or Ba/Al ratio have been used as a proxy for productivity in the Arabian Sea, the elevated Ba/Al ratio has been attributed to high productivity due to increased upwelling and/or increased runoff and nutrient supply during interglacial periods (see Weedon and Shimmield, 1991; Shimmield, 1992; Reichard et al., 1997; Shenetgar et al. 2000). The Ba/Al ratio is however negatively correlated with OC (Table 2). The concentrations of redox-sensitive elements are also low in this part of the core (profiles of $\mathrm{Cu}, \mathrm{Ni}, \mathrm{Zn}, \mathrm{U}, \mathrm{Mo}, \mathrm{Cd}$ in Fig. 5 and Fig. 7). The lowest sedimentation rates make the sediments in this part of the core more susceptible to 'burndown' of organic matter and thus post-depositional oxygenation of organic carbon and redistribution of elements is perhaps responsible for low $\mathrm{OC}, \mathrm{Cu}, \mathrm{Ni}, \mathrm{Zn}, \mathrm{Cd}, \mathrm{Mo}$ and $\mathrm{U}$. The increased AIR content and total clay volume (Fig. 3) attest for the increase in terrigenous influx that may have diluted $\mathrm{OC}$ in bottom sediments.

\subsubsection{Holocene sediments}

Strong peaks of high $\chi_{\text {If }}$ (Fig. 4), low concentrations of $\mathrm{OC}, \mathrm{Cu}, \mathrm{Ni}, \mathrm{Zn}, \mathrm{Ba}, \mathrm{CaCO}_{3}$ (Fig. 5), and pulses of relatively high peaks of Th/Al, Sc/Al, Rb/Al and to some extent K/Al (Fig. 6) during the early Holocene suggest increased terrigenous flux and decreased biogenic or organicassociated flux. Strongly reduced $\delta^{18} \mathrm{O}$ values (Fig. 3) suggest maximum intensity of the southwest monsoon during this period. Wet and warm climate might have resulted in strong chemical weathering and influx of detrital matter from land. The progressive increase in $\mathrm{OC}$, $\mathrm{Ba} / \mathrm{Al}, \mathrm{Cu} / \mathrm{Al}, \mathrm{Ni} / \mathrm{Al}$ and $\mathrm{Zn} / \mathrm{Al}$ from early to late Holocene, and strong correlation of $\mathrm{OC}$ with all these elements (Table 2) and $\mathrm{CaCO}_{3}(r=0.83)$ suggest increasing surface productivity. Stronger SW monsoon winds may have induced strong coastal upwelling (Van Campo et al., 1982) that resulted in high productivity in surface waters and burial of high OC and other 
productivity related or organic-associated elements. Despite oxygenated bottom waters prevailing in Holocene and present day, $\mathrm{OC}$ values are high in late Holocene and, similar to that of glacial sediments which experienced reducing conditions (Fig. 5). This suggests that productivity is major controlling factor for organic-rich sediments. Low concentrations of $U$, Mo and $\mathrm{Cd}$ in Holocene than in glacial sediments (Fig. 7) suggest that the Holocene sediments could not achieve strong reducing conditions because of oxygenated bottom waters.

4.3 Role of diagenesis in dissolution and precipitation of magnetic minerals Liu et al. (2004) identified four stages of sediments that correspond to the affects of progressive early diagenesis. Stage 1 is least affected by diagenesis with high concentrations of detrital magnetite and hematite. Stage 2 shows the presence of pyrite and decreasing concentrations detrital magnetite. Stage 3 is marked by progressive loss of hematite with depth and minimum magnetite and, stage 4 with enhanced concentrations of authigenic magnetic minerals such as greigite or pyrrhotite. The profiles of magnetic parameters (Fig. 4) exhibit all stages of diagenesis, but not in the sequence as one proceeds down core. (a) A trough of low values of all magnetic concentration, grain size and mineralogy variables in sediments of the last $7 \mathrm{kaBP}$ indicates stage 2 diagenesis. High OC and relatively high rates of sedimentation (Figs. 2-3) may have favoured reductive diagenesis and dissolution of magnetic minerals, the process that has been documented by numerous studies (Leslie et al., 1990; Karlin, 1990; Bloemendal et al., 1993; Kumar et al., 2005; Rao et al., 2008). (b) High amplitude peaks in $\chi_{\text {If }}$ with parallel peaks in $\chi_{\text {ARM }}, S I R M$, and S-ratio between 7 and $11 \mathrm{kaBP}$ are associated with low OC and peaks of high concentrations of terrigenous elements (Figs. 4 and 6). This part may represent least diagenesis of magnetic minerals and corresponds to stage 1 of Lieu et al. (2004). (c) The peaks of high $\chi_{\text {If }}$ at $\sim 10 \mathrm{ka}, 18 \mathrm{ka}, 20 \mathrm{ka}$ and $25 \mathrm{ka}$ match with low $\chi_{\mathrm{ARM}}$, SIRM, $\chi_{\text {ARM }} / \chi_{\text {If }}$, $\chi_{A R M} / S I R M$ and S-ratio (see Fig. 4). Decrease in $\chi_{\text {ARM }}$ and grain size ratios could mean that the fine-grained magnetite particles are selectively dissolved during early diagenesis. This corresponds to stage $2 / 3$ diagenesis (Liu et al., 2004). (d) For a given $\chi_{\text {If }}$ peak, $\chi_{\text {ARM }}, \chi_{\text {ARM }} \chi_{\text {Iff }}$, $\chi_{\text {ARM }}$ /SIRM peaks have increased at certain intervals ( 17 and $\left.\sim 22 \mathrm{kaBP}\right)$, indicating increase of fine-grained, ferrimagnetites (see Fig. 4). High S-ratios (of $\sim 0.95$ ) indicate dominance of an extremely low-coercivity magnetic phase. Variations in grain size can be caused by compositional sorting during sedimentation or variation in the proportion of authigenic magnetic 
minerals such as greigite or pyrrhotite in a typical anoxic environment, or caused by magnetotactic bacterial enhancement below redox fronts (Roberts et al., 1996; Hounslow and Maher, 1999; Rey et al., 2005). These intervals are associated with highest concentrations of $\mathrm{U} / \mathrm{Al}, \mathrm{Mo} / \mathrm{Al}$ and $\mathrm{Cd} / \mathrm{Al}$ (see Fig. 7) indicating strong sulphate reducing conditions (see above). High S-ratios may not be related to detrital fine-magnetite or biogenic bacterial magnetite, as these magnetic phases get dissolved at strong reducing conditions. The increased fine-grained ferrimagnetic phase may therefore be due to the formation of new magnetic mineral in strong redox conditions. Roberts (1995) pointed out the occurrence of authigenic greigite in single domain-like state is typical of anoxic environment, especially in the presence of numerous redox-sensitive elements. Greigites usually display high-coercivities. However, the substitution of $\mathrm{Ni}$ and $\mathrm{Cr}$ in its crystal structure may give rise to the low coercivities, relative to those documented for greigite (Roberts et al., 1999). We therefore suggest a new ferrimagnetic mineral, probably greigite is forming at these intervals. The glacial sediments showing high $\mathrm{OC}$, strong reducing anoxic conditions and new magnetic minerals appear analogous to that of sapropels from the eastern Mediterranean Sea (Roberts et al., 1999; Passier et al., 2001) and thin light sediment layers in the Japan Sea (Vigliotti, 1997; Hayashida et al., 2007), which are known for diagenetic magnetic enhancement. The sediments of 17 - 24 ka BP thus showed intervals of magnetic dissolution (eg. 18, 20 and 25 kaBP- dark bands in Fig. 4)) alternate with authigenic growth of secondary magnetic phases ( 17 and 22 kaBP - light bands in Fig. 4); this may be due to the result of fluctuating redox conditions that reflect paleoproductivity changes during this time.

The rock magnetic and geochemical record of this core SK 148/4 (Figs. 4 and 7) was compared with that of core AAS 62/2 (Fig. 9). Both cores exhibit stage 1 and 2/3 diagenesis at intervals in Holocene. However, the records strongly differ during glacial times: Core AAS 62/2 exhibits high $\mathrm{OC}$, distinctly low magnetic concentration, grain size and mineralogy parameters and low concentrations of Mo and $U$. Despite development of reductive diagenetic conditions wherein magnetic minerals got dissolved, there is little enrichment of $U$ and Mo (Fig. 9). This is due to remobilization of redox-sensitive elements into the water column because of intermittent bioturbation (Rao et al., 2008). The 17-28 kaBP sediments of the core thus represent sulfate reduction to intermittent oxic conditions. On the other hand, the core SK 148/4 shows intervals 
of reductive diagenesis alternating with intervals of enhanced authigenic ferrimagnetites (Fig. 4, section 4.3) and, high OC, Mo, $U$ and $C d$ (Fig. 7; section 4.2.1)). Stronger reductive diagenesis and anoxic sedimentary conditions and low oxygenated bottom waters are characteristic of glacial sediments. While both the cores were recovered from near similar depths and oxygenated present day bottom waters, sedimentary conditions during glacial period differed within $440 \mathrm{~km}$ (distance between two cores). This is due to differences in biological productivity, reworking of upper slope sediments and sedimentation rates. Using a suite of biomarkers (alkenones, dinosterol, brassicasterol) Schulte et al. (1999) showed oxygenated bottom waters during the last $330 \mathrm{kyr}$ in a core from the equatorial Indian Ocean and, varied intensity of the oxygen minimum zone (OMZ) (including completely vanished $\mathrm{OMZ}$ at times) in a core from the northeastern Arabian Sea during the last $65 \mathrm{kyr}$. Using OC, $\sum$ alkenone, $\delta^{13} \mathrm{C}$ and $\delta^{15} \mathrm{~N}$ data in a core from the eastern Arabian Sea (off Goa) Banakar et al. (2005) showed increased productivity and reduced denitrification during the last glacial maximum (LGM). We therefore suggest that the prevalence of low oxygenated bottom water during glacial times should not be generalized.

\section{Acknowledgements}

We thank the Directors of the National Institute of Oceanography, National Centre for Antarctic and Ocean Research, Goa and Indian Institute of Geomagnetism, Mumbai for facilities and encouragement. Part of the geochemical work was carried out by Meloth Thamban (MT) at the Geological Survey of Japan, Tsukuba through financial support from the Japan Science Promotion Society (JSPS). MT thanks Prof. Hodaka Kawahata for extending the facilities. Part of this work was carried out from the project funds of Department of Science and Technology, New Delhi. We thank the reviewers of this paper for their insight and critical comments that improved our understanding of the processes suggested in the paper. 


\section{References}

Agnihotri, R., M. M., Sarin, B. L. K. Somayajulu, A.J.T. Jull and G.S. Burr (2003): Late Quaternary biogenic productivity and organic carbon deposition in the eastern Arabian Sea. Palaeogeo. Palaeoclimat. Palaeoecol., 197, 43-60.

Banakar, V. K., T. Oba, A. R. Chodankar, T. Kusamato, M. Yamamoto, and M. Minagawa (2005): Monsoon related changes in sea surface productivity and water column denitrification in the eastern Arabian Sea during the last glacial cycle. Mar. Geol., 219, 99108.

Bloemendal, J., B. Lamb and K. W. King (1988): Paleoenvironmental implications of rockmagnetic properties of late Quaternary sediment cores from the eastern equatorial Atlantic. Paleoceanography, 3, 61-87.

Bloemendal, J., J. W. King, A. Hunt, et al., (1993): Origin of sedimentary magnetic record at Ocean Drilling Program sites on the Owen Ridge, Western Arabian Sea. J. Geophys. Res., 98, 4199-4219.

Chaillou, G., P. Anschutz, G. Lavaux, J. Schafer and G. Blanc (2002): The distribution of Mo, U, and $\mathrm{Cd}$ in relation to major redox species in muddy sediments of the Bay of Biscaye. Mar. Chem., 80, 41-59.

Chase, X. and R. F. Anderson (2001): Evidence from authigenic uranium for increased productivity of the glacial Subantarctic Ocean, Palaeoceanography, 16, 468-478.

Clemens, S. C. and W. L. Prell (1990): Late Pleistocene variability of Arabian Sea summer monsoon winds and continental aridity: eolian records from the lithogenic component of deep sea sediments. Paleoceanography, 5, 109-145.

Crusius, J., S. E. Calvert, T. Pederson and D. Sage (1996): Rhenium and Molybdinum enrichments in sediments as indicators of oxic, sub-oxic and sulfidic conditions of deposition. Earth Planet. Sci. Lett., 145, 65-78.

Duplessy, J. G. (1982): Glacial to interglacial contrast in the northern Indian Ocean. Nature, 295, 494-498. 
Dymond, J., E. Suess and M. Lyle (1992): Barium in deep sea sediments: a geochemical proxy for paleoproductivity. Paleoceanography, 7, 163-181.

Gobeil, C., R. W. MacDonald, and B. Sundby. (1997): Diagenetic separation of cadmium and manganese in suboxic continental margin sediments. Geochim. et Cosmochim, Acta, 61, 4647-4654.

Hayashida,A., S. Hattori and H. Oda (2007): Diagenetic modifications of magnetic properties observed in a piston core (MD01-2407) from the Oki Ridge, Japan Sea, Palaeogeo. Palaeoclimat. Palaeoecol., 247, 65-73.

Hermelin, J. O. R. and G. B. Shimmield (1990): The importance of the oxygen minimum zone and sediment chemistry in the distribution of recent benthic foraminifera in the northwest Indian Ocean. Mar. Geol., 91, 1-29.

Hounslow, M. W. and B. A. Maher (1999): Source of the climate signal recorded by magnetic susceptibility variations in the Indian Ocean sediments. J. Geophys. Res., 104, 5047-5061.

Jickells, T. D., W.G. Deuser and A. H. Knap (1984): The sedimentation rates of trace elements in the Sargasso Sea measured by sediment traps. Deep-Sea Res., Part A, 31, 1169-1178.

Karlin, R., (1990): Magntite diagenesis in marine sediments from Oregan continental margin, J. Geophys. Res., 95, 4405-4419.

Kumar, A. A., V. P. Rao, S. K. Patil, P. M. Kessarkar and M. Thamban (2005): Rock magnetic records of the sediments of the eastern Arabian Sea: evidence for late Quaternary climatic change. Mar. Geol., 220, 59-82.

Leslie, B. W., S. P. Lund and D. E. Hammond (1990): Rock magnetic evidence for the dissolution and authigenic growth of magnetic minerals within anoxic marine sediments of the California continental boarderland. J. Geophys. Res., 95, 4437-4452.

Liu, J., R. Zhu, A. P. Roberts, S. Li and J. H. Chang (2004): High resolution analysis of early diagenetic effects on magnetic minerals in Post-middle Holocene continental shelf sediments from the Korea Straight. J. Geophys. Res., 109, B 03103, 1-15.

Mallik, T. K., V. Vasudevan, P. A. Verghese and T. Machado (1987): The black sand placer deposits of Kerala beach, Southwest India. Mar. Geol., 77, 129-150. 
Morford, J. L., and S. Emerson (1999): The geochemistry of redox sensitive trace metals in sediments. Geochim. Cosmochim. Acta, 63, 1735-1750.

Nameroff, T. J., L. S. Balistrieri, and J. W. Murray (2002): Suboxic trace elemental geochemistry in the eastern tropical North Pacific. Geochim. Cosmochim. Acta, 66, 11391158.

Oldfield, F. (1991): Environmental magnetism - A personal prospective. Quat. Sci. Rev., 10, 73-85.

Paropkari, A. L., C. P. Babu and A. Mascarenhas (1992): A critical evaluation of depositional parameters controlling the variability of organic carbon in the Arabian Sea sediments. Mar. Geol., 107, 213-226.

Passier, H. F., G. J. de Lange and M. J. Dekkers (2001): Magnetic properties and geochemistry of the active oxidation front and the youngest sapropel in the eastern Miditerranean Sea. Geophys. J. Inter., 145, 604-614.

Pattan, J. N., Masuzowa, T., Naidu, P. D., G. Parthiban and M. Yamamoto (2003): Productivity fluctuations in the southeastern Arabian Sea during the last 140 ka. Palaeogeo. Palaeoclimat. Palaeoecol., 193, 575-590.

Prakashbabu, C., H-J. Brumsack, B. Schnetger and M. E.Bottcher (2002): Ba as a productivity proxy in continental margin sediments: a study from the eastern Arabian Sea. Mar. Geol., 184, 189-206.

Prell, W. L., D. W. Murray and S. C. Clemens (1992): Evolution and variability of the Indian Ocean summer monsoon: Evidence from the Western Arabian Sea Drilling Program. In: Duncan, R.A., Rea, D.K., Kidd, R.B., von Rad, U., Weissel, J.K., (Eds.) Synthesis of results from the Scientific Drilling in the Indian Ocean. American Geophysical Union, Geophysical Monograph 70, 447-469.

Rao, V. P., M. Lamboy and P. A. Dupeuble (1993): Verdine and other associated authigenic (glaucony, phosphate) facies from the surficial sediments of the southwestern continental margin of India. Mar.Geol., 111, 133-158.

Rao, V. P., P. M. Kessarkar, S. K. Patil and S. M. Ahmad (2008): Rock magnetic and geochemical record in a core from the eastern Arabian Sea: diagenetic and environmental 
implications during the late Quaternary. Palaeogeo. Palaeoclimat. Palaeoecol., 270, 4652.

Rao, V. P. and B. G. Wagle (1997): Geomorphology and surficial geology of the western continental shelf and slope of India: A Review. Curr. Sci., 73, 330-350.

Reichart, G. J., M. den Dulk, H. J. Visser, C. H. Vander Weijden, and W. K. Zachariasse (1997): A $225 \mathrm{kyr}$ record of dust supply, paleoproductivity and the oxygen minimum zone from the Murray Ridge (northern Arabian Sea). Palaeogeo. Palaeoclimat. Palaeoecol., 134, 149-169.

Reichart, G. J., S. J. Schenau, G. J. de Lange, and W. J. Zachariasse (2002): Synchroneity of oxygen minimum zone intensity on the Oman and Pakistan margins at sub-Milankovitch time scales. Mar. Geol., 185, 403-415.

Rey, D., K. J. Mohamed, A. Bernabeu, B. Rubio, and F. Vilas (2005): Early diagenesis of magnetic minerals in marine terrestrial environments: geochemical signatures of hydrodynamic forcing. Mar. Geol., 215, 215-236.

Roberts, A. P. (1995): Magnetic properties of greigite $\left(\mathrm{Fe}_{3} \mathrm{~S}_{4}\right)$ Earth Planet. Sci. Lett., 134, $227-$ 236.

Roberts, A. P., R. L. Reynolds, K. L. Verosub, and D. P. Adam (1996): Environmental magnetic implications of greigite $\left(\mathrm{Fe}_{3} \mathrm{~S}_{4}\right)$ formation in a 3 m.y. lake sediment record from Butte Valley, northern California. Geophys. Res. Lett., 23, 2859-2862.

Roberts, A. P., J. S. Stoner, and C. Richter (1999): Diagenetic magnetic enhancement of sapropels from the eastern Mediterranean Sea. Mar. Geol., 153, 103-116.

Robinson, S. G., J. T. S. Sahota, and F. Oldfield (2002): Early diagenesis in North Atlantic abyssal plain sediments characterized by rock magnetic and geophysical indices. Mar. Geol., 163, 77-107.

Rosenthal, Y., P. Lam, E. A. Boyle, and A. Thomson (1995): Authigenic Cd enrichments in suboxic sediments. Precipitation and post-depositional mobility. Earth Planet. Sci. Lett., 132, 99-111. 
Rostek, F., E. Bard, L. Beafort, C. Sonzogni, and G. Ganssen (1997): Sea surface temperature and productivity record for the past $240 \mathrm{kyrs}$ in the Arabian Sea. Deep-Sea Res., Part II, 44, 1461-1480.

Sarkar, A., R. Ramesh, S. K. Bhattacharya, and G. Rajogopalan (1990): Oxygen isotopic evidence for a stronger winter monsoon current during the last Glaciation. Nature 343, 549-551.

Sarkar, A., S. K. Bhattacharya, and M. M. Sarin (1993): Geochemical evidence for anoxic deep water in the Arabian Sea during the last glaciation. Geochim. Cosmochim. Acta, 57, 10091016.

Schenau, S. J., M. A. Prins, G. J. de Lange, and C. Monnin (2001): Barium accumulation in the Arabian Sea: Controls on barite preservation in marine sediments. Geochim. Cosmochim. Acta, 65, 1545-1556.

Schnetger, B., H.-J. Brumsack, H. Schale, J. Henrichs, and L. Dittert (2000): Geochemical characteristics of deep-sea sediments from the Arabian Sea: a high resolution study. Deep-Sea Res., Part II, 47, 2735-2768.

Schulz, H., von Rad, U. and H. Erlenkeuser (1998): Correlation between Arabian Sea and Greenland climate oscillations of the past 110,000 years. Nature, 393, 54-57.

Schulte, S., F. Rostek, E. Bard, J. Rullkotter, and O. Marchal (1999): Variation of oxygen minimum and primary productivity recorded in sediments of the Arabian Sea. Earth Planet. Sci. Lett., 173, 205-221.

Shimmield, G. B. (1992): Can sediment Geochemistry record changes in coastal upwelling paleoproductivity? Evidence from Northwest Africa and the Arabian Sea. In: Summerhayes, C. P., Prell, W. L. and Emis, K.-C (Eds.) Upwelling systems: Evolution since the Early Miocene, Geol. Soc. London Spec. Publi. 64, 29-46.

Shimmield, G. B. and S. R. Mowbray (1991): The inorganic geochemical record of the northwest Arabian Sea: A history of productivity variation over the last 400 ky from site 722 and 724. Proceedings of Ocean Drilling Program Scientific Results 117, 409-429.

Shimmield, G. B., S. R. Mowbray, and G. P. Weedon (1990): A 350 ka history of the Indian Southwest Monsoon.- evidence from deep-sea cores, northwest Arabian Sea. Trans. Royal Society Edinburg: Earth Sci., 81, 289-299. 
Singh, A. D., D. Kroon and R. S. Ganeshram (2006): Millennial scale variations in productivity and OMZ intensity in the eastern Arabian Sea. J. Geol. Soc. India, 68, 369-378.

Sinha, A., K. G. Cannariato, L. D. Stott, H.-C. Li, C.-F. You, H. Cheng, R. L. Edwards, and I. B. Singh (2005): Variability of Southwest Indian summer monsoon precipitation during the Bolling-Allerod. Geology, 33, 813-816.

Sirocko, F., M. Sarnthein, H. Erlenkeuser, H. Lange, M. Arnold, J.-C. Duplessy (1993): Centuary scale events in monsoonal climate over the past 24,000 years. Nature, 364, 322324.

Sirocko, F., D. Garbe-Schonberg, A. Mclntyre, B. Molfino (1996): Teleconnections between the subtropical monsoons and high latitude climates during the last deglaciation. Science, 272, 526-529.

Sirocko, F., D. Garbe-Schonberg, and C. Devey (2000): Processes controlling trace element geochemistry of Arabian Sea sediments during the last 25,000 years. Global Planetary Change, 26, 217-303.

Stuiver, M., P. J. Reimer and R. W. Reimer (2005): CALIB 5.02 (Program and documentation) http:/www.calib.qua.ac.uk/.

Thamban, M., V. P. Rao, R. R. Schneider, and P. M. Grootes (2001): Glacial to Holocene fluctuations in hydrography and productivity along the southwestern continental margin of India. Palaeogeo. Palaeoclimat. Palaeoecol., 165, 113-127.

Thamban, M., V. P. Rao, and S. V. Raju (1997): Controls on organic carbon distribution in sediments from the eastern Arabian Sea margin. Geo-Marine Lett., 17, 220-227.

Thomson, J., S. Nixon, I. W. Croudace, T. F. Pederson, L. Brown, G. T. Cook, and A. B. Mackenzie (2001): Redox sensitive element uptake in north east Atlantic Ocean sediments (Benthic Boundary layer experimental sites). Earth Planet. Sci. Lett., 184, 535-547.

Tiwari, M., R. Ramesh, B. L. K. Somayajulu, A. J. T. Jull, and G. S. Burr (2005): Early glacial ( 19-17 ka) strengthening of the northeast monsoon. Geophys. Res. Lett., 32, L19712, 14. 
Van Campo, E., J.-C. Duplessy, and M. Rossignol-A Strict (1982): Climatic conditions deduced from a 150-kyr oxygen isotope-pollen record from the Arabian Sea. Nature, 296, 56-59.

Van der Weijden, C. H., G.J. Reichart and B. J. H. Vanos (2006): Sedimentary trace element records over the last $200 \mathrm{kyr}$ from within and below the northern Arabian Sea Oxygen minimum zone. Mar. Geol., 231, 69-88.

Van der Weijden, C. H., G. J. Reichart, and H. J. Visser (1999): Enhanced preservation of organic matter in sediments deposited within the oxygen minimum zone in the northeastern Arabian Sea. Deep-Sea Res., Part 1, 46, 807-830.

Vigliotti, L. (1997): Magnetic properties of light and dark sediment layers from the Japan Sea: Diagenetic and palaeiclimatic implications. Quat. Sci. Rev., 16, 1093-1114.

Vigliotti, L., L. Capotonde and M. Torh (1999): Magnetic properties of sediments deposited in suboxic -anoxic environments: relationships with biological and geochemical proxies. In: Tarling, D. H., and Turner, P., (Eds.) Palaeomagnetism and diagenesis in sediments. Geological Society of London Spl. Publication 151, 71-83.

von Rad, U., H. Schulz, V. Riech, M. den Dulk, U. Berner, and F. Sirocko (1999): Multiple monsoon-controlled breakdown of oxygen minimum conditions during the past 30,000 years documented in laminated sediments off Pakistan. Palaeogeo. Palaeoclimat. Palaeoecol., 152, 129-161.

Von Stackelberg, U. (1972): Faziesverteilung in sedimenten des indisch-pakistanischen kontinentalrandes. "Meteor" Forschungs-Ergebnisse C (9), 1-73.

Weedon, G.P. and G. B. Shimmield (1991): Late Pleistocene upwelling and productivity variations in the Northwest Indian Ocean deduced from spectral analyses of geochemical data from sites 722 and 724 In: Prell, W. L., Niitsuma N. et al. (Eds.), Proceedings of Ocean Drilling Program, Scientific Results, 117, 409-429.

Zheng, Y., A. van Geen, and R. P. Anderson (2000): Intensification of the northeast Pacific oxyzen minimum zone during the Bolling- Allerod warm period. Palaeoceanography, 15, 528-536. 
Figure captions

Fig. 1. Location of sediment cores: SK 148/4, SK 20/185, AAS 62/2 and SS 3827G. Base map and currents are adopted from Tiwari et al. (2005). Direction of the northeast monsoon currents (NEMC) and salinity contours (nos. 32-35) for that period are also given. SCSomali current, LH- Laccadive High, EICC-East India Coastal Current, WICC-West India Coastal Current. T- Thiruvananthapuram.

Fig. 2. Depth vs. Age of the sediments in core SK 148/4. Sedimentation rates for different intervals are also shown. Ages of the sediment intervals dated are shown in Table 1.

Fig. 3. Down core variations of $\delta^{18} \mathrm{O}$, $\chi_{\mathrm{lf}}$, acid-insoluble residue (AIR), clay volume, organic carbon (OC), mass accumulation rate (MAR) of $O C$ and linear sedimentation rates (LSR) in core SK 148/4, YD-Younger Dryas, B-A - B $\phi l l i n g-$ Aller $\phi d$ event, Marine isotope stages 1,2 and 3 are also shown.

Fig. 4. Down core variations of percent $\mathrm{OC}$ and rock magnetic concentration, grain size and mineralogy parameters in core SK 148/4.

Fig. 5. Down core variations of $\mathrm{OC} / \mathrm{Al}, \mathrm{Cu} / \mathrm{Al}, \mathrm{Ni} / \mathrm{Al}, \mathrm{Zn} / \mathrm{Al}, \mathrm{CaCO}_{3}, \mathrm{Sr} / \mathrm{Al}$, and $\mathrm{Ba} / \mathrm{Al}$ in core SK 148/4. Small vertical dashed line is the Al-normalized ratio of the Post-Archean Australian Shale (PAAS).

Fig. 6. Down core variations of $\chi_{\mathrm{lf}}, \mathrm{Fe} / \mathrm{Al}, \mathrm{K} / \mathrm{Al}, \mathrm{Rb} / \mathrm{Al}, \mathrm{Sc} / \mathrm{Al}, \mathrm{Zr} / \mathrm{Al}, \mathrm{Th} / \mathrm{Al}$, and $\mathrm{V} / \mathrm{Al}$ in core SK 148/4. Small vertical dashed line is the Al-normalized ratio of the Post-Archean Australian Shale (PAAS). 
Fig. 7. Down core variations of OC/Al, Cd/Al, Mo/Al, U/Al and U/Sc in core SK 148/4. Small vertical dashed line is the Al-normalized ratio of the Post-Archean Australian Shale (PAAS).

Fig. 8. $\delta^{18} \mathrm{O}$ records of Globigerinoides ruber between 15 and $25 \mathrm{kaBP}$ in different sediment cores in the southeastern and equatorial Arabian Sea. SK 148/4 - this paper, SK 20/185 (Sarkar et al., 1990), AAS 62/2 (Rao et al., 2008) and SS 3827G (Tiwari et al., 2005). Note - scale change both in $X$-axis and $Y$ - axis for each graph.

Fig. 9. Down core variations of OC, rock magnetic concentration $\left(\chi_{\text {If }}, \chi_{\text {ARM }}\right)$, grain size $\left(\chi_{\text {ARM }} /\right.$ $\left.\chi_{\mathrm{If}}\right)$ and mineralogy (S-ratio) parameters, and Mo/Al and U/Al ratios in core AAS 62/2 (modified after Rao et al., 2008). 
Table 1

Accelerator Mass Spectrometer (AMS) ages of sediment intervals dated in the core SK 148/4

\begin{tabular}{|l|l|l|l|l|}
\hline $\begin{array}{l}\text { Depth interval } \\
\text { in the core }(\mathrm{cm})\end{array}$ & $\begin{array}{l}\text { Lab code at } \\
\text { WHOI }\end{array}$ & $\begin{array}{l}\text { Measured } \\
\text { Age (years) }\end{array}$ & $\begin{array}{l}\text { Error } \\
\text { Age }\end{array}$ & $\begin{array}{l}\text { Calibrated } \\
\text { Age }(2 \sigma) \\
\text { range (years) }\end{array}$ \\
\hline $17-20$ & 47668 & 3070 & 45 & $2454-2879$ \\
$51-54$ & 47669 & 6280 & 35 & $6398-6743$ \\
$70-73$ & 47670 & 9350 & 50 & $9739-10209$ \\
$97-100$ & 47671 & 14050 & 65 & $15646-16512$ \\
$148-154$ & 47672 & 19500 & 70 & $22265-22665$ \\
\hline
\end{tabular}

WHOI - Woods Hole Oceanographic Institution, USA

\section{Table 2}

Correlation coefficient of Al-normalized ratios of biogenic/organic elements

\begin{tabular}{|c|c|c|c|c|c|c|}
\hline $\begin{array}{l}\text { Element / } \\
\text { Period }\end{array}$ & $\begin{array}{l}\text { OC vs. } \\
\text { Cu/Al }\end{array}$ & $\begin{array}{l}\text { OC vs. } \\
\mathrm{Ni} / \mathrm{Al}\end{array}$ & $\begin{array}{l}\text { OC vs. } \\
\text { Zn/Al }\end{array}$ & $\begin{array}{l}\text { OC vs. } \\
\text { Ba/Al }\end{array}$ & $\begin{array}{l}\mathrm{CaCO}_{3} \\
\text { vs. Ba/Al }\end{array}$ & $\begin{array}{l}\text { OC vs. } \\
\mathrm{CaCO}_{3}\end{array}$ \\
\hline $\begin{array}{l}\text { Holocene } \\
<11 \text { kaBP }\end{array}$ & $\begin{array}{l}0.9 \\
(n=18)\end{array}$ & $\begin{array}{l}0.94 \\
(n=18)\end{array}$ & $\begin{array}{l}0.95 \\
(n=18)\end{array}$ & $\begin{array}{l}0.94 \\
(n=18)\end{array}$ & $\begin{array}{l}0.83 \\
(n=18)\end{array}$ & $\begin{array}{l}0.50 \\
(n=27)\end{array}$ \\
\hline $\begin{array}{l}\text { Deglacial } \\
11-17 \text { kaBP }\end{array}$ & $\begin{array}{l}0.76 \\
(n=8)\end{array}$ & $\begin{array}{l}0.71 \\
(n=8)\end{array}$ & $\begin{array}{l}0.81 \\
(n=8)\end{array}$ & $\begin{array}{l}0.35 \\
(n=8)\end{array}$ & $\begin{array}{l}-0.61 \\
(n=8)\end{array}$ & $\begin{array}{l}0.09 \\
(n=9)\end{array}$ \\
\hline $\begin{array}{l}\text { Glacial } \\
17-24 \text { kaBP }\end{array}$ & $\begin{array}{l}-0.35 \\
(n=14)\end{array}$ & $\begin{array}{l}-0.24 \\
(n=14)\end{array}$ & $\begin{array}{l}-0.26 \\
(n=14)\end{array}$ & $\begin{array}{l}0.51 \\
(n=17)\end{array}$ & $\begin{array}{l}0.60 \\
(n=17)\end{array}$ & $\begin{array}{l}0.5 \\
(n=17)\end{array}$ \\
\hline $\begin{array}{l}\text { Pre-glacial } \\
24-35 \text { kaBP }\end{array}$ & $\begin{array}{l}-0.05 \\
(n=15)\end{array}$ & $\begin{array}{l}0.11 \\
(n=15)\end{array}$ & $\begin{array}{l}0.34 \\
(n=15)\end{array}$ & $\begin{array}{l}0.27 \\
(n=15)\end{array}$ & $\begin{array}{l}0.61 \\
(n=15)\end{array}$ & $\begin{array}{l}0.04 \\
(n=16)\end{array}$ \\
\hline
\end{tabular}




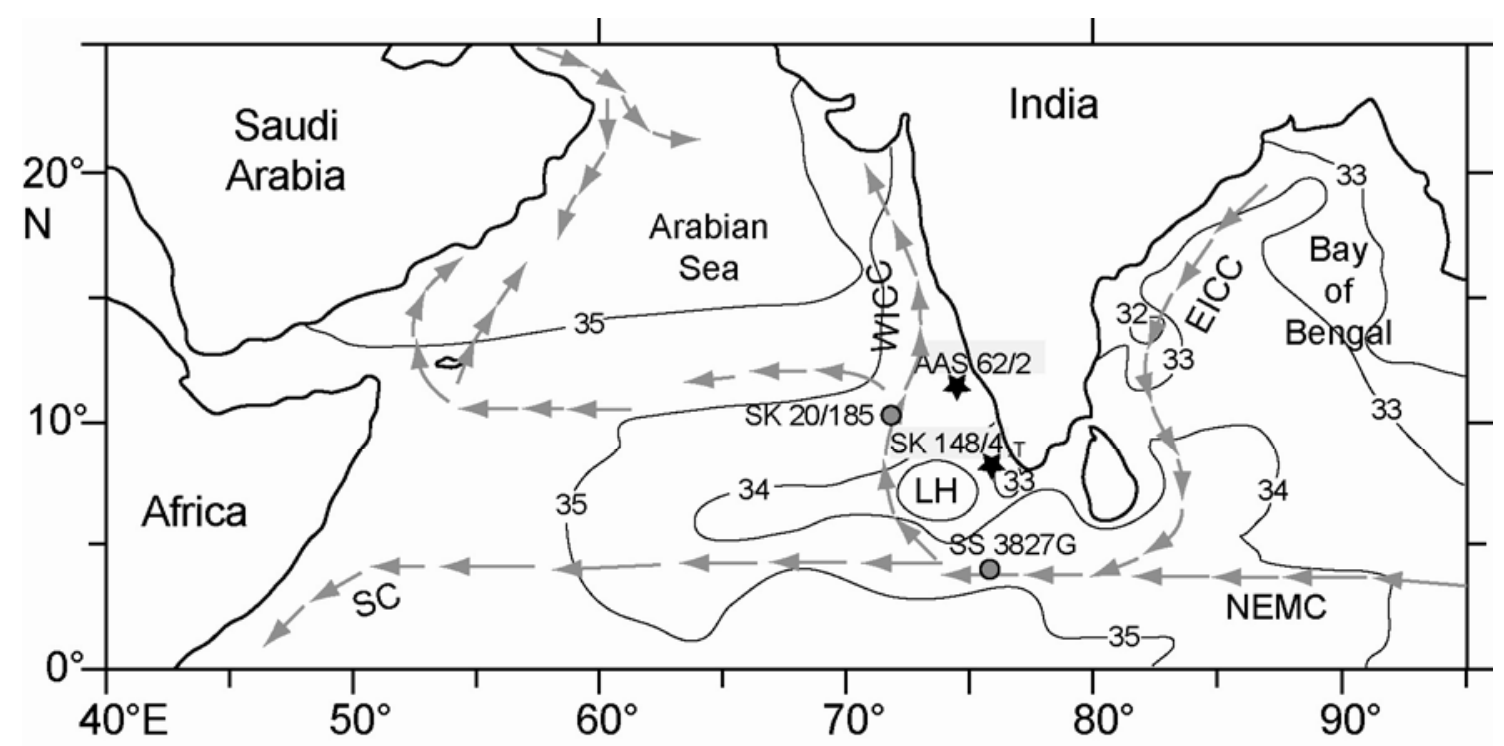

Fig. 1 


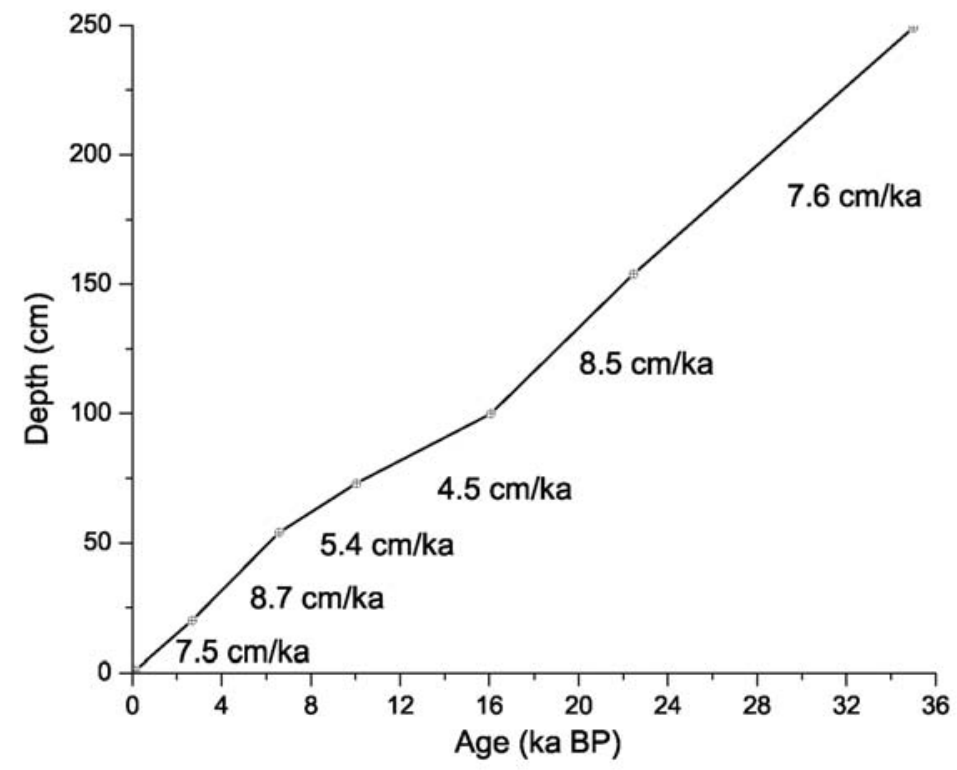

Fig. 2 


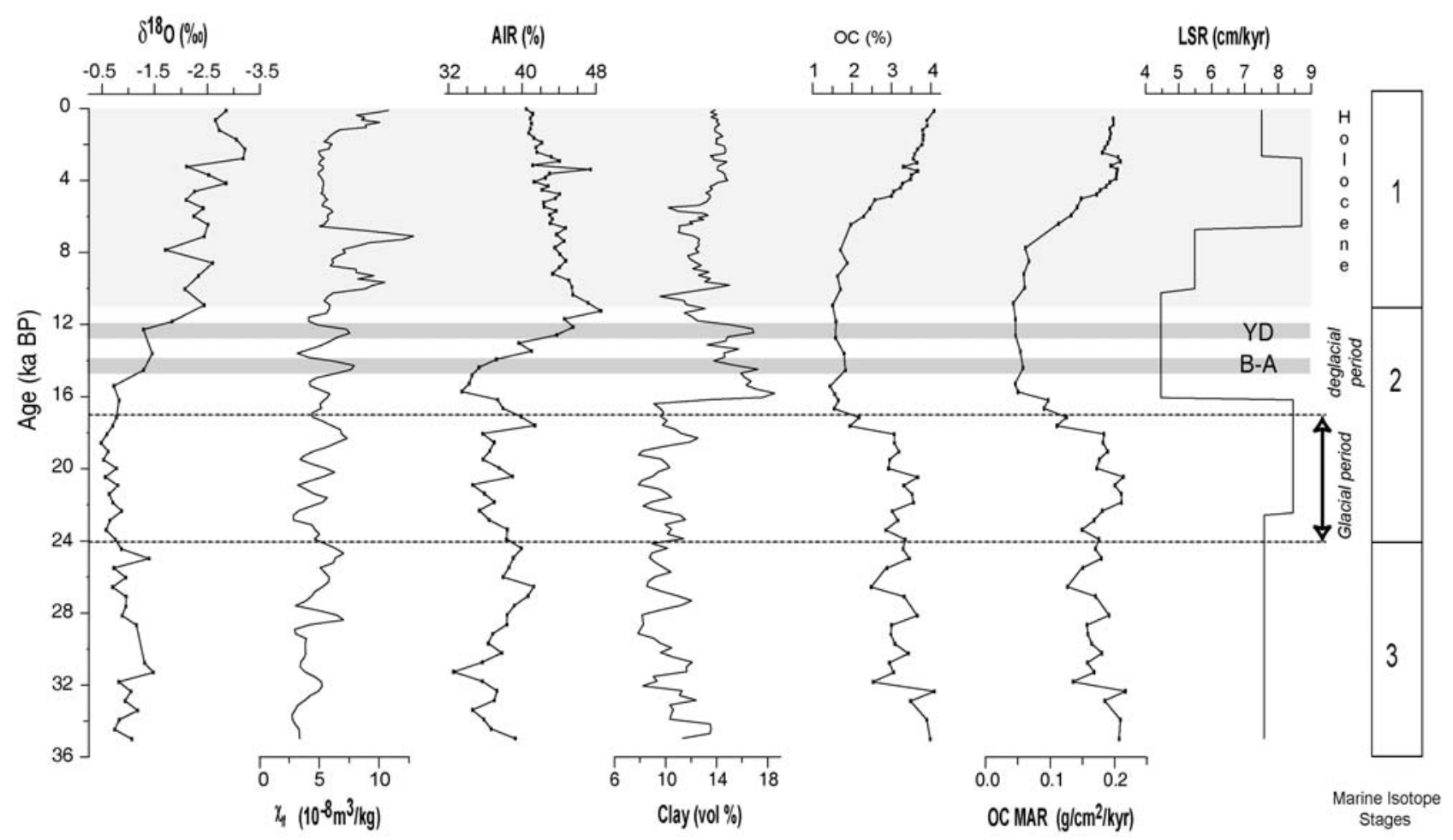

Fig. 3 


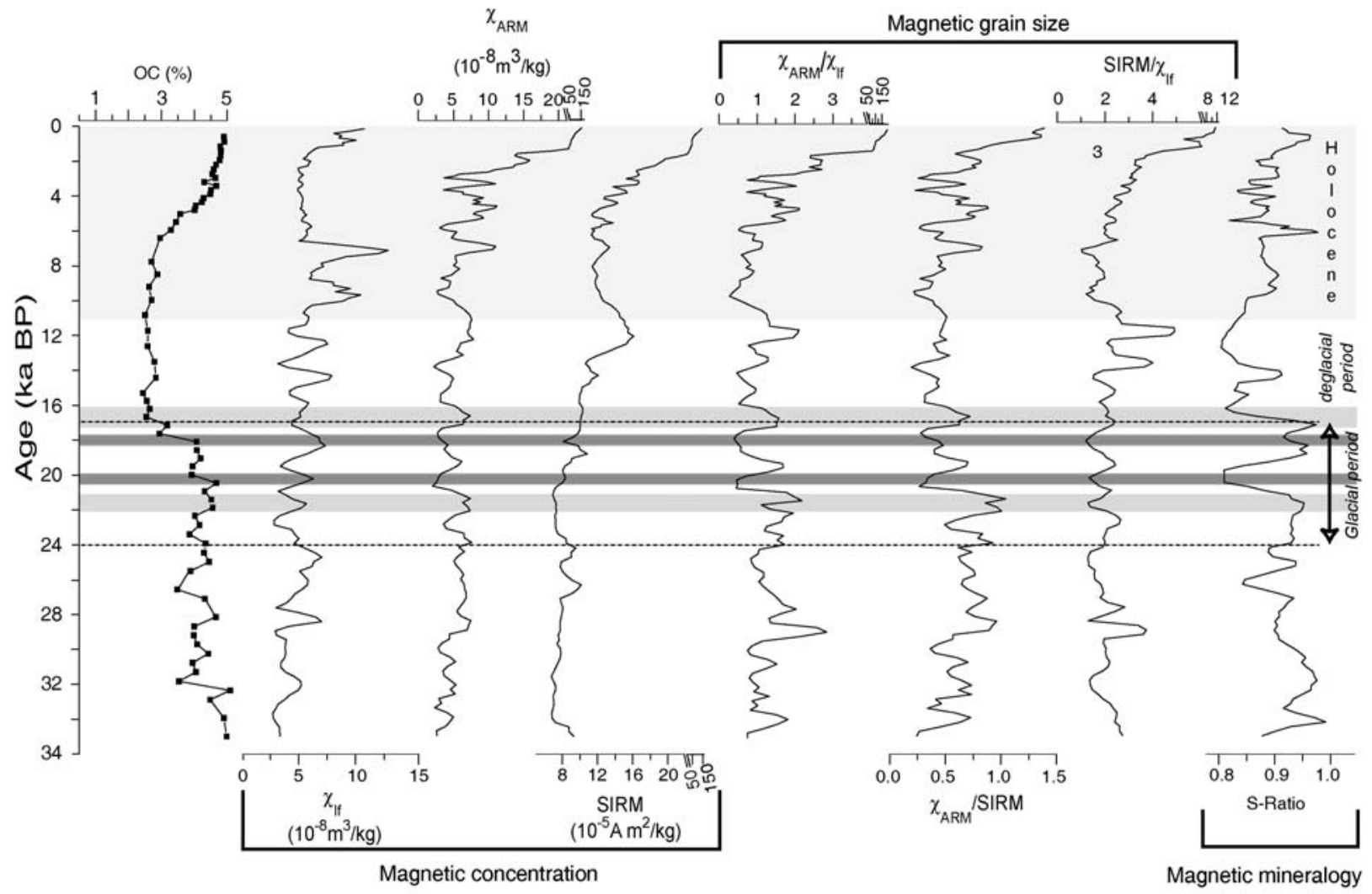

Fig. 4 


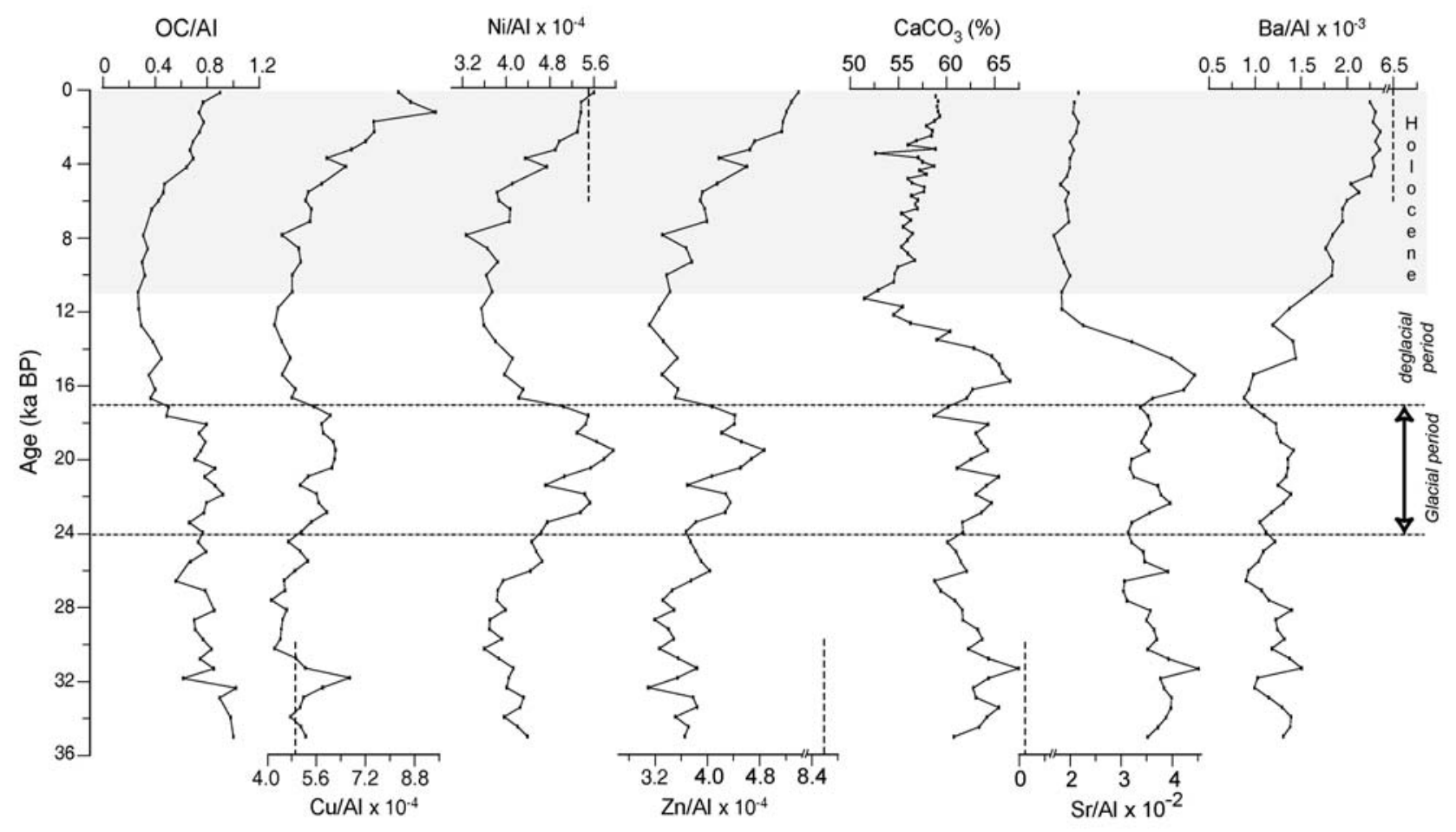

Fig. 5 


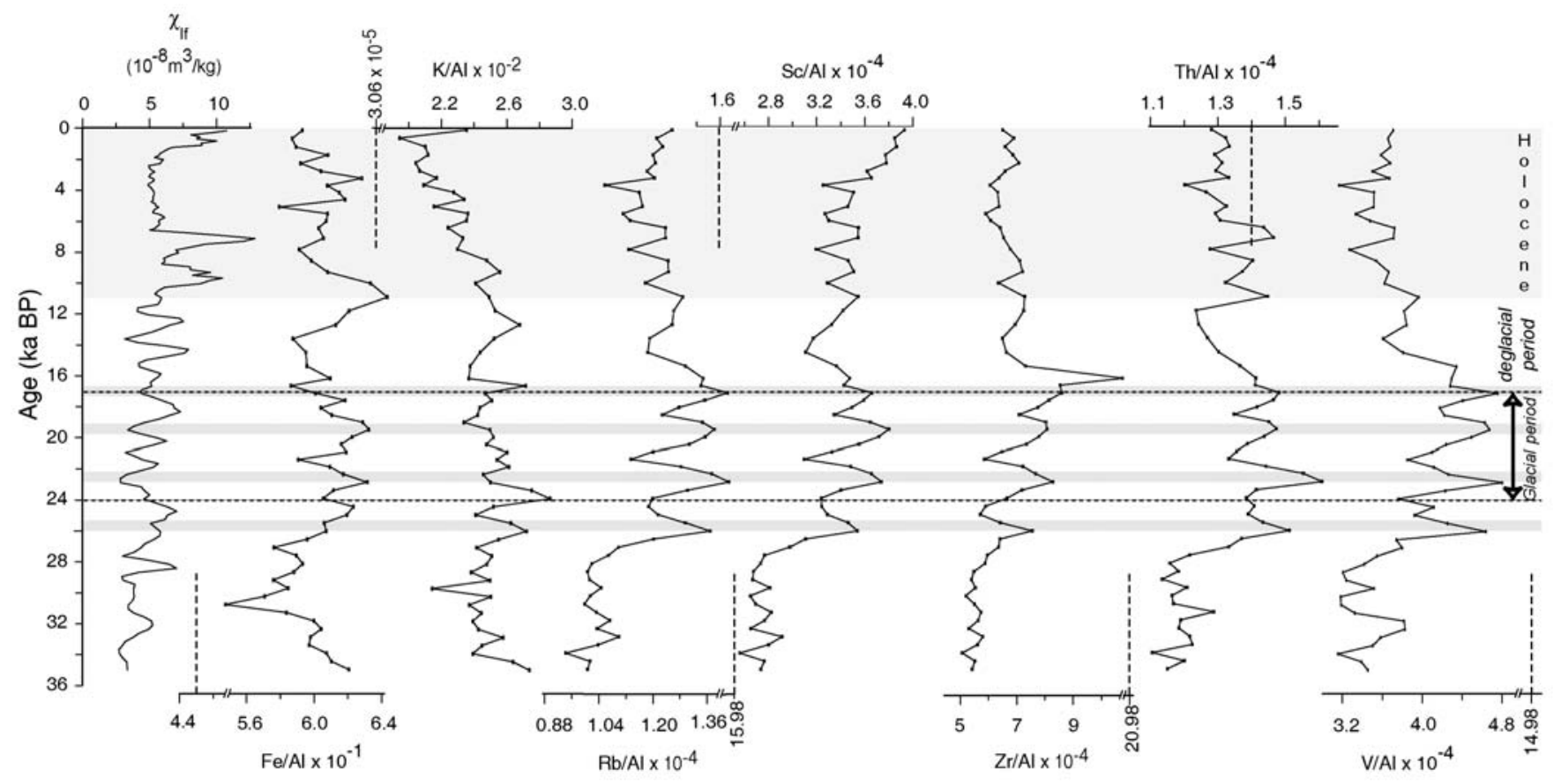

Fig. 6 


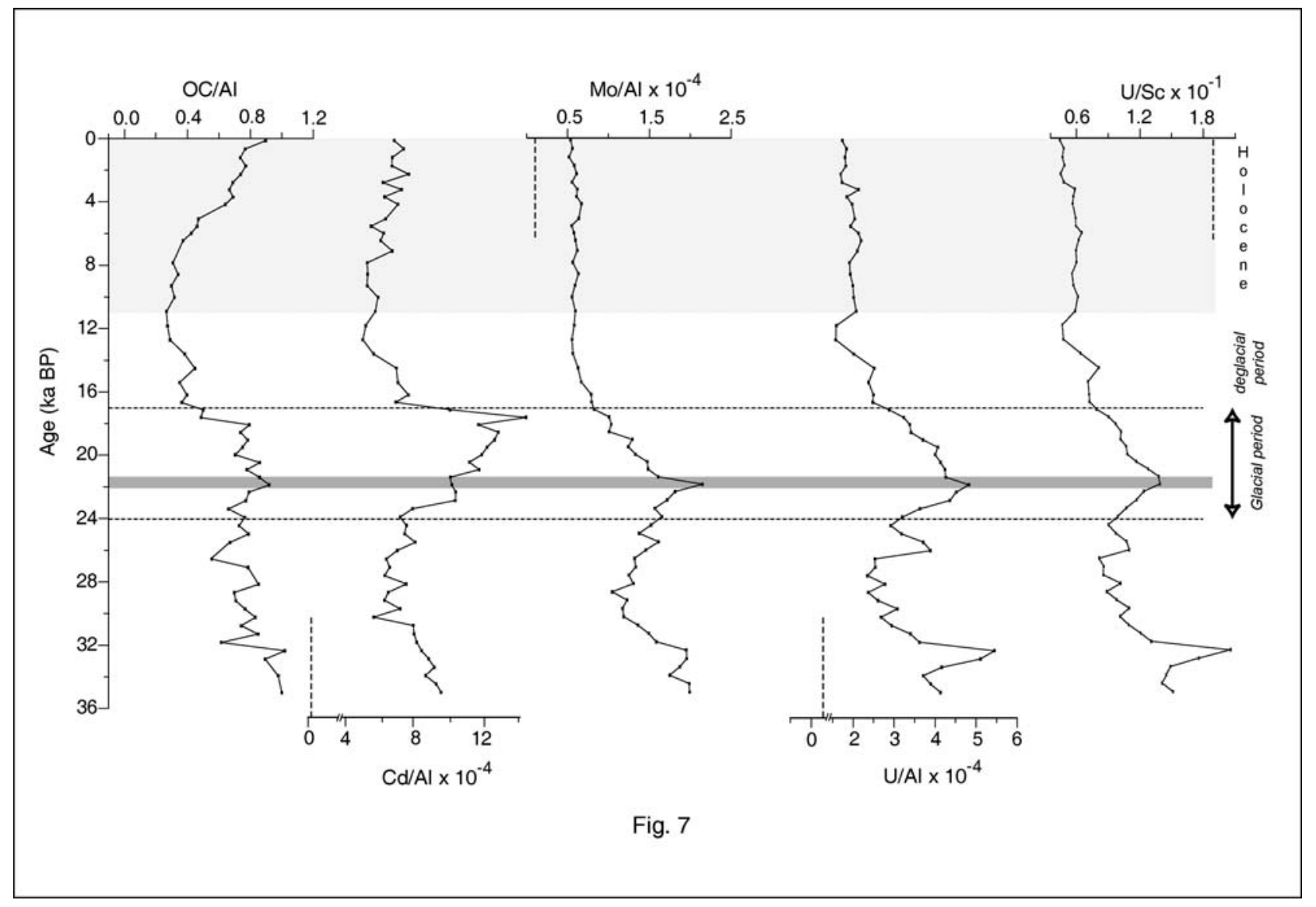




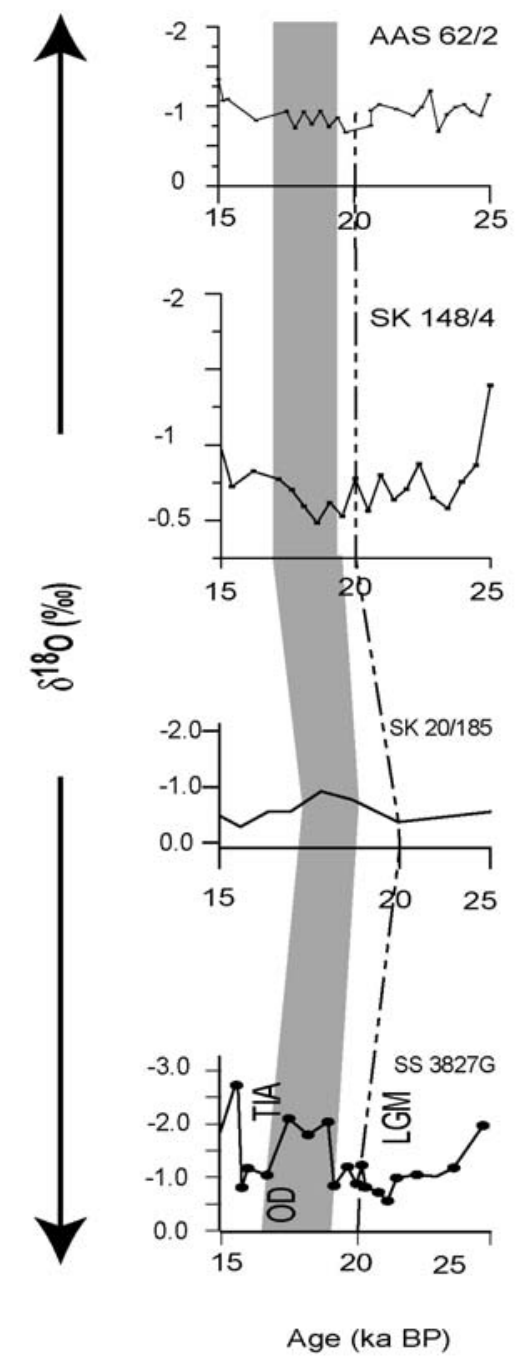

Fig. 8 


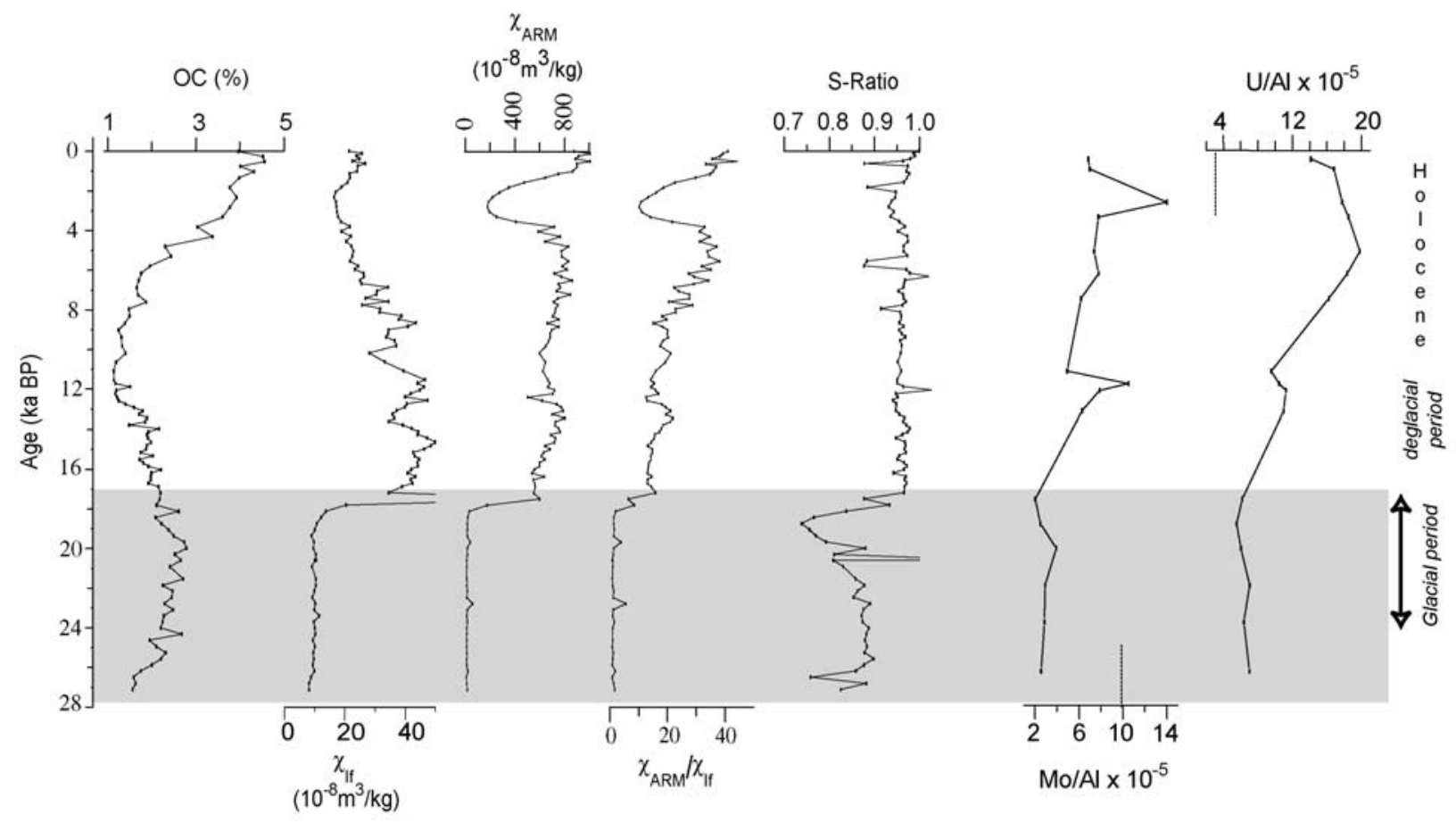

Fig 9 